\title{
February 23 and March 8: Two Holidays that Upstaged the February Revolution
}

\author{
Elizabeth A. Wood
}

On March 8, 1920, Russian feminist Aleksandra Kollontai praised International Women's Day demonstrations as "an excellent method of agitation," a day to draw women into the political sphere and raise their consciousness. For Kollontai, March 8, 1917 was a day never to forget. On that day "Russian women raised the torch of proletarian revolution and set the world on fire. The February revolution marks its beginning from this day."1

March 8 would go on to be celebrated in different ways over the next 100 years, but it would not be celebrated as the start of the February Revolution. Of course, one might argue, since March 8, 1917 in Russia was February 23 in Europe (because of the 13-day difference between the two calendars), one might have expected February 23 to be celebrated as the start of the February Revolution. Yet that too was not the case. Instead, during the period of the Russian Civil War, February 23 became Red Army Day. March 8 remained International Women's Day. And March 12, the equivalent of February 27 (Old Style), was decreed as the "Day of the Overthrow of the Autocracy."

The leading historians of the February Revolution agree that the start of the strike wave that culminated in the overthrow of the tsar broke out on February 23 with the beginning of the women's strike for peace, bread, and suffrage (for the latter, see Rochelle Ruthchild's article in this issue of Slavic Review). ${ }^{2}$ How then did February 23/March 8 end up not being celebrated as the beginning of the February Revolution?

The simple answer is that in the summer of 1917 the Provisional Government chose February 27 as "The Day of the Great Russian Revolution,” marking the anniversary of the formation of the Temporary Committee of the State Duma, which evolved into the Provisional Government. On October 29, 1917 the new Bolshevik government included that holiday in its decree "On the

The author would like to thank Rochelle Ruthchild and Saule Dairabayeva for significant input into this article, as well as the Davis Center for Russian and Eurasian Studies at Harvard for library privileges that permitted the extensive use of the East View Database for this article.

1. "International Women’s Day" (1920), at www.marxists.org/archive/kollonta/1920/ womens-day.htm (last accessed July 31, 2017). First published: Mezhdunarodnyi den' rabotnits, Moscow 1920. Trans. Alix Holt, 1972.

2. One could, of course, argue that the beginning of the revolution came earlier with the sporadic strikes in January and February, or later with the full crisis of the autocracy (Nicholas II abdicated March 2). Nonetheless the majority of historians argue for February 23 as the start of the revolution: Tsuyoshi Hasegawa, The February Revolution, Petrograd 1917 (Seattle, 1981); William Henry Chamberlin, The Russian Revolution, 1917-1921 (New York, 1935; reprinted 1987, 2014); Lev Trotskii, The History of the Russian Revolution, v. 1, ch. 5 (Five Days, February 23-27, 1917), at www.marxists.org/archive/trotsky/1930/hrr/ ch07.htm (last accessed July 13, 2017). See also, I. Krupskaia [sic], "K istorii prazdnovaniia Mezhdunarodnogo zhenskogo dnia v Rossii," Krasnyi arkhiv 87, 1938, 3-18, at https://dlibeastview-com.ezp-prod1.hul.harvard.edu/browse/doc/46305757 (last accessed on July 13, 2017, restricted access). 
Eight-Hour Day," renaming it "The Day of the Overthrow of the Autocracy."3 On December 10, 1918, they moved it to March 12 since the calendar had been changed by then. ${ }^{4}$

Yet March 12 seems to have barely been celebrated. It was listed as an official non-working holiday until 1930 when Stalin cut back all the holidays to just January 1, May 1, and November 7, but there do not seem to have been large-scale celebrations. ${ }^{5}$ On one level this is understandable. The post-1917 rulers of Soviet Russia cast February as a "bourgeois" revolution, the first stage in the Marxist revolution that would install a bourgeois government (the Provisional Government) as a stepping stone to creating a full-fledged socialist revolution. February thus served as merely a prologue to October, the Great Socialist Revolution. By the time of the tenth anniversary on March 12, 1927, Izvestiia's leading headline read "February-A Step Toward October," while Pravda on the same day noted "How the Path from February to October was marked.”6

3. Further research would be needed to know their reasoning. February 27 was also the founding of the Petrograd Soviet and the moment when the soldiers became decisively involved. Mark Steinberg in his new monograph, The Russian Revolution, 1905-1921 (Oxford, 2017), 21, claims February 27 as "the defining moment" of the revolution because the armed regiments came over to the side of the revolution. That does not necessarily make it the beginning of the revolution or the most logical moment to celebrate the revolution, however.

4. In Russian the holiday was called Den' nizverzheniia samoderzhaviia. Petr Mul'tatuli, “Ob otrechenii Imperatora Nikolaia II ot prestola," Russkaia narodnaia liniia, at http://ruskline.ru/analitika/2015/11/08/ob_otrechenii_imperatora_nikolaya_ii_ot_ prestola/ (last accessed July 13, 2017). Contemporaries also occasionally acknowledged that February 23 was "the first day of mass demonstrations" and that women played a significant part, but often buried that information in the middle of their articles, e.g., Ya. A. Yakovlev, "Fevral'skie dnie 1917 g." Izvestiia, March 8, 1927, 2-3, at https://dlibeastview-com.ezp-prod1.hul.harvard.edu/browse/doc/24809819 (last accessed July 13, 2017, restricted access).

5. A thorough search of the available secondary literature on holidays comes up with almost no mention of significant celebrations of March 12: Malte Rolf, Soviet Mass Festivals, 1917-1991 (Pittsburgh, 2013); Richard Stites, Revolutionary Dreams: Utopian Vision and Experimental Life in the Russian Revolution (Oxford, 1988); Richard Stites, "The Origins of Soviet Ritual Style: Symbol and Festival in the Russian Revolution" in Claes Arvidsson and Lars Erik Blomqvist, eds., Symbols of Power: The Esthetics of Political Legitimacy in the Soviet Union and Eastern Europe (Stockholm, 1987), 23-42; Boris Kolonitskii and Orlando Figes, Interpreting the Russian Revolution: The Language and Symbols of 1917 (New Haven, 1999); Christel Lane, The Rites of Rulers: Ritual in Industrial Society-The Soviet Case (Cambridge, Eng., 1981). The one celebration came on March 12, 1919 when the Red Army studio performed "The Overthrow of the Autocracy." James Von Geldern, Bolshevik Festivals, 1917-1920 (Berkeley, 1993), 125-27; also mentioned in Natalia Murray, "Street Theatre as Propaganda: Mass Performances and Spectacles in Petrograd in 1920." Studies in Theatre and Performance 36.3 (2016): 235; N. A. Gorchakov, Istoriia sovetskogo teatra (New York: izd.im. Chekhova, 1956), 78.

6. "Fevral'-etap k Oktiabriu," Izvestiia, March 12, 1927, 1, at https://dlib-eastviewcom.ezp-prod1.hul.harvard.edu/browse/doc/24811944 (last accessed July 13, 2017, restricted access). There is no mention of women on this page. The lead article in Pravda on the same date reads "From the Crown to the Hammer and Sickle," "Ot korony k serpu i molotu," at https://dlib-eastview-com.ezp-prod1.hul.harvard.edu/browse/doc/21684759 (last accessed July 13, 2017, restricted access). Other articles celebrated the "bourgeois" revolution" and the path from February to October: "O burzhuaznoi revoliutsii v nashei 
It would also appear, however, that over the course of the early 1920s, the connection between the women's demonstrations on February 23/March 8 and the February Revolution was actively undermined. Women's activism on that day was consistently demoted as "backward," "unskilled," and "spontaneous"; after all, the Bolshevik V. N. Kaiurov had tried to persuade them not to take to the streets. Yet this cannot be the whole story since Tsuyoshi Hasegawa has given evidence that women textile workers were the only ones able to sustain an entire month-long strike in January-February 1917. ${ }^{7}$ The bigger picture is one of gender politics and gender relations. As Choi Chatterjee has argued, the two main parts of the revolutionary year 1917, the February and October Revolutions were, from early in Soviet history, themselves cast as "feminine" and "masculine" respectively, with the second valorized at the expense of the first. ${ }^{8}$

Over time the new Soviet authorities gradually came to celebrate two different holidays at the same time as the February Revolution: the holidays of February 23 (Red Army Day) and March 8 (International Women's Day). The celebration of these two holidays in turn fostered an understanding of binary spheres of activism. Red Army Day celebrated soldiers, ostensibly male and female, but over time became increasingly recognized as "men's day." International Women's Day (or The Day of Women Workers, Den' rabotnits) celebrated, at least initially, women's emancipation and their entry into full Soviet citizenship. Ostensibly men and women were equal. By the 1970s the holidays had evolved so that on February 23 women gave presents to men, especially those in the military and their fathers, while on March 8 men gave flowers and chocolates to women, especially teachers and mothers. On the one hand, this would appear to mark a nice symmetry of two rather anodyne holidays.

In fact, however, I would argue that this bifurcation of two holidays reinforced a prerevolutionary gender binary that was antithetical to the stated goals of gender equality. The creators of these two holidays were sending a gender message of supposed parity-two holidays for two sexes-that actually served to reify gender differences and naturalize them rather than eliminating or undermining them. Because of the conversion of the calendar (which Russians still recognize today in celebrating New Year's Day on both January 1 and January 14), these two holidays would have been widely recognized in the early decades as de facto the same day. Thus on two equivalent days, one holiday evolved to recognize men's (and theoretically women's) participation in the military and another to recognize women's participation in the home.

In general, holidays provide a key window on social values, both the official ones being promulgated by the authorities (both central and local), and

strane" and "Kak namechen byl put' ot Fevralia k Oktiabriu," Pravda, March 12, 1927, 2, at https://dlib-eastview-com.ezp-prod1.hul.harvard.edu/browse/doc/21684755. Only one article mentioned women and their role in the revolution: "Rabotnitsa v revoliutsii," Izvestiia, March 12, 1927, 58, at https://dlib-eastview-com.ezp-prod1.hul.harvard.edu/ browse/doc/24811946.

7. Hasegawa, February Revolution, 202 (for strikes); 216-17 (for Kaiurov).

8. Choi Chatterjee, Celebrating Women: Gender, Festival Culture, and Bolshevik Ideology, 1919-1939 (Pittsburgh, 2002), 38. 
also the ones that are actually accepted and promoted by the general population. Holidays provide an ordering of the year and they create a sense of community and common emotions. ${ }^{9}$ They demonstrate who holds the authority to create the holidays in the first place, and who does not. They highlight what is to be remembered and what is to be forgotten or glossed over. ${ }^{10}$

In the case of the holidays of February 23 and March 8, it seems significant that both of them emerged as holidays that gave gifts. In Thank You, Comrade Stalin, Jeffrey Brooks has argued that much of Soviet propaganda was organized around what he calls the "economy of the gift," in which the authorities (especially Stalin, but the state as well) were seen to give gifts (both material and structural, even metaphysical, such as the possibility of happiness), while the population was expected to (and did) make a show of gratitude. ${ }^{11}$ Much of this evolved in the 1930s, but as we shall see, the holiday of February 23 first emerged as "the Day of the Red Present" in 1918, so more research needs to be done on this.

Holidays also reinforce gender norms. Who gives presents to whom; who is celebrated; where does the celebration take place-these are all questions of social construction. Gender is then imbibed by the population not just by the official ideology (in the Soviet case an ideology of emancipation and mobilization into the public sphere) but also by practice: the practice of giving women flowers and giving boys and men tanks and vodka.

\section{Creating a Women's Holiday}

Of the two new holidays, March 8-International Women's Day-was the older. It had an important international and prerevolutionary history since Clara Zetkin had proposed the creation of the holiday at the International Women's Conference of the Second International in Copenhagen in 1910. The Social Democrats had organized demonstrations on March 8 in major

9. One thinks here of Victor Turner's work on structure and communitas in his Dramas, Fields, and Metaphors: Symbolic Action in Human Society (Ithaca, 1974).

10. For excellent analysis of the "work" of holidays and festivals, see Rolf, Soviet Mass Festivals. The field of memory studies in Russian studies is now enormous, but particularly fine and trend-setting works have been: Catherine Merridale, Night of Stone: Death and Memory in Russia (New York, 2001); Nina Tumarkin, Lenin Lives!: The Lenin Cult in Soviet Russia (Cambridge, Mass. 1997); Fred Corney, Telling October: Memory and the Making of the Bolshevik Revolution (Ithaca, 2004); Lisa A. Kirschenbaum, The Legacy of the Siege of Leningrad, 1941-1995: Myth, Memories, and Monuments (New York, 2006); Melissa Kirschke Stockdale, "United in Gratitude: Honoring Soldiers and Defining the Nation in Russia's Great War," Kritika: Explorations in Russian and Eurasian History 7, no. 3 (2006): 459-85; Sergei Oushakine, The Patriotism of Despair: Nation, War, and Loss in Russia (Ithaca, 2009); Karen Petrone, The Great War in Russian Memory (Bloomington, 2011); Elizabeth A. Wood, "Performing Memory: Vladimir Putin and the Celebration of World War II in Russia,” The Soviet and Post-Soviet Review 38, no. 2 (2011): 172-200; Stephen M. Norris, Blockbuster History in the New Russia: Movies, Memory, and Patriotism (Bloomington, 2012).

11. Jeffrey Brooks, Thank You, Comrade Stalin!: Soviet Public Culture from Revolution to Cold War (Princeton, 2000). Also some discussion of gratitude in Sheila Fitzpatrick, "Happiness and Toska: An Essay in the History of Emotions in Pre-war Soviet Russia." Australian Journal of Politics \& History 50, no. 3 (2004): 362. 
Russian cities from 1913.12 Various hypotheses have been put forward as to why the Bolsheviks began to pay attention to women workers in 1913 after studiously ignoring them for decades (except for Nadezhda Krupskaia's The Woman Worker in 1899). To me it seems obvious that the key dynamic was Tsarist legislation in 1912, finally giving women the vote and the right to be elected to factory insurance committees, as well as women workers becoming increasingly involved in strikes, labor disruptions, and being drawn to feminist appeals for equal rights. ${ }^{13}$

In short order after 1917, the March 8 holiday was separated from the start of the Russian Revolution, even though during 1917 that connection was still strong. On March 7, the banner headline of Pravda read "A Great Day," and exulted: "One week ago, on February 23, in Petrograd the old authorities interfered with women workers' celebrating their day. Because of this the first clashes happened in the Putilov Factory, which turned into demonstrations and into the revolution. The first day of the revolution is Women's day, Women Workers' International Day. Glory to the Woman! Glory to the International!" 14 Yet by February 23, 1922, a leading Pravda article announced that the first step from the February to the October Revolutions, the demonstrations that started it all, should be dated from February 24, 1917..$^{15}$ February 23 and the women's demonstrations were completely ignored. On March 8, 1922, only one small article in Pravda even mentioned "women's day," focusing narrowly on the struggles of women printers. ${ }^{16}$

The March 8 holiday was also domesticated. Of course, suffrage was immediately removed as an issue since the Provisional Government had given women the vote. ${ }^{17}$ At the same time, a key part of the larger Bolshevik mission was to have Zhenotdel, as an arm of the Communist Party, replace any and all remaining "women's" organizations since they could be potentially feminist and independent, linking them under official party control and making them

12. Chatterjee, Celebrating Women; Rochelle Ruthchild, "From West to East: International Women's Day, the First Decade,” Aspasia, 6 (2012): 1-24; and Ruthchild, Equality and Revolution: Women's Rights in the Russian Empire, 1905-1917 (Pittsburgh, 2010).

13. Elizabeth A. Wood, The Baba and the Comrade: Gender and Politics in Revolutionary Russia (Bloomington, 1997), 33. For other hypotheses see Chatterjee, Celebrating Women, 20, 167n27.

14. “Velikii den'," Pravda, March 7 (20), 1917, 1, at https://dlib-eastview-com.ezp-prod1. hul.harvard.edu/browse/doc/21158759 (last accessed July 13, 2017, restricted access).

15. S. I. Ventsov, "Krasnaia armiia za chetrye goda revoliutsii," Pravda, February 23, 1922, 2-3, at https://dlib-eastview-com.ezp-prod1.hul.harvard.edu/browse/doc/21671217 (last accessed July 13, 2017, restricted access). Mikhail Sidlin first made this point in "Krasnyi podarok: K Mezhdunarodnomu zhenskomu dniu 23 fevralia," Nezavisimaia gazeta, February 22, 1997, at https://dlib-eastview-com.ezp-prod1.hul.harvard.edu/browse/ doc/298371 (last accessed July 13, 2017, restricted access).

16. N. Loginskii, “Nelegkii put'," Pravda, March 8, 1922, 6, at https://dlib-eastviewcom.ezp-prod1.hul.harvard.edu/browse/doc/21671764 (last accessed July 13, 2017, restricted access). For images of the holidays, see examples here: "Prazdnik godovshchiny krasnoi armii. Den' krasnogo podarka. II [February] 23, 1919,” at http://redavantgarde. com/content/placard/205/205.jpg (last accessed August 8, 2017); as well as a placard for the February 23 holiday, at http://svadbashokolad.ru/data/i22.jpg (last accessed August 8, 2017).

17. Ruthchild, Equality and Revolution. 
transmission belts for party directives. In the 1920s, the "women's" holiday seems to have been used instrumentally to draw women into party organizations while at the same time trying to develop more public services for women, such as childcare, public cafeterias, and laundries. ${ }^{18}$

Above all, March 8 became an opportunity for the paternalist Soviet state to demonstrate its "care" (zabota) for women, a claim that had value for both international and domestic propaganda. ${ }^{19}$ First Lenin in the 1920 s and then Stalin in the 1930s became the saviors of women. On March 8 women promised to "fulfill the precepts of Lenin." 20 By the late 1930s, women were often portrayed as shock workers, entering into male fields as super-productive workers, but receiving silk blouses as their reward. ${ }^{21}$ As Chatterjee shows, gifts to women played an important part of this holiday from the beginning through the provision of food and prizes to women (and some men) who attended the official celebrations. ${ }^{22}$

\section{Creating a Men's Holiday}

The explanation of why Red Army Day was celebrated on February 23 from at least 1922 and possibly earlier has always been rather "difficult to discover," as no less an authority than E. H. Carr pointed out. ${ }^{23}$

Soviet citizens throughout the Soviet period were told that February 23 represented the day of the founding of the Red Army. In fact, however, the Red Army was officially founded by the Third Congress of Soviets on January 15 (28), 1918..$^{24}$ Another common myth, promulgated especially in the Soviet Union, was that February 23 was chosen because it was the day of the Red Army's victory over Kaiser Wilhelm's German army. As Stalin's Short History of the Communist Party exulted: "The Soviet Government issued the call: 'The Socialist fatherland is in danger!' In response the working class energetically began to form regiments of the Red Army. The young detachments of the new army ... heroically resisted the German marauders.... . At Narva and Pskov the German invaders met with a resolute repulse. ... February 23the day the forces of German imperialism were repulsed-is regarded as the

18. Chatterjee, Celebrating Women; Mary Buckley, Women and Ideology in the Soviet Union (Ann Arbor, 1989).

19. Chatterjee, Celebrating Women. My thanks to Rochelle Ruthchild for reminding me of the point about propaganda.

20. Cited in Chatterjee, Celebrating Women, 74.

21. Chatterjee, Celebrating Women, 133. In this, one could say they were continuing the tradition of the women's Battalion of Death of 1917, which was created to shame men into serving the state: Melissa K. Stockdale, “'My Death for the Motherland Is Happiness': Women, Patriotism, and Soldiering in Russia's Great War, 1914-1917.” The American Historical Review 109, no. 1 (2004): 78-116; Laurie Stoff, They Fought for the Motherland: Russia's Women Soldiers in World War I and the Revolution (Lawrence, 2006).

22. See also Wood, Baba and Comrade, 85-93, on the delegate meetings that made sure to serve food as a way of attracting women to attend.

23. Edward Hallett Carr, The Bolshevik Revolution (New York, 1953), v. 3, $63 \mathrm{n} 2$.

24. S'ezdy Sovetov Soiuza SSR, soiuznykh i avtonomnykh sovetskikh sotsialisticheskikh respublik: Sbornik dokumentov, 1917-1937 gg. (Moscow, 1959), 28; Mark von Hagen, Soldiers in the Proletarian Dictatorship (Ithaca, 1990), 21. 
birthday of the Red Army."25 The reality, however, was that on that day the young Soviet Army suffered a series of routs which resulted in the Germans occupying (not being defeated at) Narva and Pskov. Worse, on that same day the Germans delivered their ultimatum that Ukraine be declared independent and the two cities of Batumi and Kars be handed over to Turkey. In this context Lenin threatened to resign in order to force the Central Committee of the Party to agree to Germany's conditions. On February 25 he roundly castigated the young fighting forces in Pravda. In his words, "the regiment refused to keep their positions, refused to defend even the Narva line, failed to fulfil the order to destroy everything and everyone in retreating, not counting the flight, chaos, incompetence, helplessness, and amateurishness." It was one thing, he explained, to beat the Kerenskiis and Russian bourgeoisie in 1917; yet quite another to beat the imperialist armies of Germany. ${ }^{26}$ In short, February 23, 1918 was certainly not a day of victory for the as yet barely functioning Red Army.

How then did February 23 end up being the date for this holiday? In January 1919, Nikolai Podvoisky, who had been involved in the initial creation of the Red Army and who now led the Supreme Military Inspectorate, called for a celebration of the Red Army. ${ }^{27}$ However, there was not enough time left in the month to have it fall on the same day as the actual anniversary (January 15/28) or even the nearest Sunday. At the end of that month (January), Lev Kamenev and the Moscow Soviet decided to combine the founding of the Red Army with a holiday created the year before (in 1918), "The Day of the Red Present” [Den' krasnogo podarka]. ${ }^{28}$ That day had been created to encourage volunteers in

25. History of the Communist Party of the Soviet Union (Bolsheviks): Short Course (Moscow, 1939), 217.

26. V. I. Lenin, “Tiazhelyi, no neobkhodimyi urok,” Pravda, February 25 (12), 1918, reprinted in Lenin, Polnoe sobranie sochinenii (Moscow, 1974), v. 35, 393-97 at http:// leninism.su/works/74-tom-35/1650-tyazhelyj\%E2\%80\%91no\%E2\%80\%91neobxodimyj \%E2\%80\%91urok.html (last accessed July 13, 2017). Discussion in Artem Krechetnikov, “23 fevralia: Istoricheskii kazus ili koniunktura?” BBC Russkaia sluzhba, at http://www. bbc.com/russian/russia/2015/02/150223_russia_defender_day (last accessed July 13, 2017). Chamberlin, Russian Revolution, 403, on Lenin's ultimatum.

27. Podvoisky at this time had recently lost power to Trotskii, who had taken over as Commissar for Army and Navy and also Chairman of the Supreme Military Council. More research needs to be done to understand his (Podvoisky's) interest in creating this new holiday.

28. “Den' Krasnoi Armii," Pravda, January 29, 1919, 3, at https://dlib-eastview-com. ezp-prod1.hul.harvard.edu/browse/doc/25859733 (last accessed July 13, 2017, restricted access). Early in 1919 the holiday was still unstable. On January 30, 1919, Izvestiia published "Day of the Red Present (Den' krasnogo podarka)," calling on all musicians to list the halls and buildings where they could hold concerts for the Day of the Red Present to be held on February 16. On February 19, Izvestiia carried articles by both names ("Red Army" and "Red Present"). Also on February 22, Izvestiia carried numerous articles on the anniversary of the founding of the Red Army, but also "Podrobnosti prazdnestva," that still referred to the holiday as "Day of the Red Present." There was one last article on Den' Krasnogo podarka on March 14, 1919 in Izvestiia, but then it does not appear again until the first historical article appeared in 1996: Mikhail Zuev, "Dni voinskoi slavy Rossii," Vestnik voennoi informatsii, January 2, 1996, at https://dlib-eastview-com.ezp-prod1. hul.harvard.edu/browse/doc/2478010 (last accessed July 13, 2017, restricted access). Zuev was a military historian. 
the rear to collect warm clothes and food for soldiers at the front. ${ }^{29}$ According to one popular historian, the idea for a Day of the Red Present had been bandied about in Bolshevik circles from the fall of 1918; initially they had wanted to link it to the celebration of the October Revolution. ${ }^{30}$ But this new combined holiday, now named Red Army Day, was so insignificant (and there were so many other holidays), that the holiday was forgotten for the next three years (1920-22). Only in 1923 did the Central Executive Committee of the Communist Party order everyone to celebrate the fifth anniversary of the Red Army on February $23 .{ }^{31}$

\section{The End of the Story?}

The holiday of the February Revolution-the "Day of the Overthrow of the Autocracy"-continued to exist in minimal form until 1930, when Stalin reduced the calendar of holidays to just three, January 1, May 1, and November 7. It appeared on so-called Red Calendars and in trade union lists of nonworking holidays. But, as noted above, there appears to be almost no record of how (if at all) it was celebrated.

International Women's Day, by contrast, was significantly upgraded in May 1965 when the Presidium of the Supreme Soviet declared it a nonworking holiday. Until that time it had been a regular workday with celebrations in the evening, though in some years women were given two hours off on that day. ${ }^{32}$ Around the same time (the 1970s), February 23 became increasingly known as a "men's holiday" designed to "balance" the "women’s holiday.” It did not, however, become a non-working holiday until 2002. ${ }^{33}$ In 2006 it was renamed "Day of the Defender of the Fatherland" (den' zashchitnika otechestva).

29. For a brief description of the spectacles, films, and parades put on that day see Robert Russell, “The Arts and the Russian Civil War,” Journal of European Studies 20, no. 3 (1990): 233.

30. Aleksandr Melenberg, “Den' Krasnogo podarka,” (originally published in Vremia $M N$, February 22, 2002) reprinted posthumously in Novaya Gazeta 18 (February 17, 2011), at https://www.novayagazeta.ru/articles/2011/02/17/6833-krasnyy-podarok (last accessed July 13, 2017).

31. “K 80-letiiu RKKA. O fevrale 1918-go bez mifov,” Suvorovskii Natisk, (February 21, 1998); https://dlib-eastview-com.ezp-prod1.hul.harvard.edu/browse/doc/2221127 (last accessed July 13, 2017, restricted access).

32. Natalia Kozlova, "Mezhdunarodnyi zhenskii den' 8 Marta kak instrument formirovaniia sovetskoi kul'tury," Zhenshchina $v$ rossiiskoi obshchestve 1(2011), at https:// cyberleninka.ru/article/v/mezhdunarodnyy-zhenskiy-den-8-marta-kak-instrumentformirovaniya-sovetskoy-politicheskoy-kultury (last accessed July 31, 2017); also Ol'ga Nikonova, "Zhenshchiny, voina i 'figury molchaniia,"” at http://magazines.russ.ru/ nz/2005/2/ni32-pr.html (last accessed July 13, 2017). Nikonova explains that March 8 was upgraded to include women veterans of WWII in honor of "their services in communist construction" and "the defense of the Motherland."

33. Federal'nyi zakon ot 29 dekabria 2004 no. 201-FE "O vnesenii izmenenii v stat'iu 112 Trudovogo kodeksa Rossiiskoi Federatsii,” at http://www.consultant.ru/ cons/cgi/online.cgi? req $=$ doc $\&$ base $=L A W \& n=50993 \&$ fld $=134 \& d s t=1000000001,0 \&$ rnd $=0.5369001597653426 \# 0$ (last accessed July 13, 2017), also cited in "Prazdniki Rossii," at https://ru.wikipedia.org/wiki/\%D0\%9F\%D1\%80\%D0\%B0\%D0\%B7\%D0\%B4\% D0\%BD\%D0\%B8\%D0\%BA\%D0\%B8_\%D0\%A0\%D0\%BE\%D1\%81\%D1\%81\%D0\%B8\%D 0\%B8 (last accessed July 13, 2017). 
At the end of the day there is much we do not know about this pair of holidays. It seems impossible at this juncture to say for sure whether the choice of February 23 as the date for Red Army Day and the Soviet installation of March 8 as International Women's Day were explicitly intended to supplant the February Revolution. Still, it seems entirely possible that celebrating the two holidays may have helped the general population ignore the start of the February Revolution. ${ }^{34}$ We also have no evidence yet as to how February 23 was celebrated in the years of WWII when women were significantly involved in the war effort and it may not yet have been the "men's day" that it definitely became from the 1970s until today. ${ }^{35}$ Yet, for all the early Bolshevik rhetoric about mobilizing women into the same spaces and activities as men, in the formative years of the Civil War two significant holidays were developed that focused on separate spaces for the military and the home.

Today, Vladimir Putin has shown clear ambivalence about celebrating the February Revolution, a holiday that, after all, marks the time when the Russian people overthrew their national leader, the Tsar of All the Russias, Nicholas II. Commentators have reacted with some surprise that in this $100^{\text {th }}$ year, there has not been more celebration of that holiday. Perhaps one should not be surprised, however, since the holiday was so quickly suppressed in the earliest years of the revolution itself.

34. Mikhail Sidlin, "Krasnyi podarok" (n15 above). Sidlin writes, "The more elaborate the celebration of Women's Day, the easier to forget about the day of the February Revolution."

35. Anna Krylova, Soviet Women in Combat: A History of Violence on the Eastern Front (Cambridge, Eng., 2011). Krylova has an excellent discussion of gender binaries. My thanks to Wendy Goldman for reminding me to think seriously about this problem. 